\title{
Human parainfluenza virus type 3 (HPIV3) induces production of IFN $y$ and RANTES in human nasal epithelial cells (HNECs)
}

\author{
Anna Lewandowska-Polak', Małgorzata Brauncajs², Edyta Paradowska ${ }^{3}$, Marzanna Jarzębska', Marcin Kurowski ", \\ Sylwia Moskwa², Zbigniew J Leśnikowski ${ }^{3}$ and Marek L Kowalski ${ }^{1,4^{*}}$
}

\begin{abstract}
Background: Human parainfluenza virus type 3 (HPIV3), while infecting lower airway epithelial cells induces pneumonia and bronchiolitis in infants and children, and may lead to asthma exacerbations in children and adults. Respiratory viruses invading the airway epithelium activate innate immune response and induce inflammatory cytokine release contributing to the pathophysiology of upper and lower airway disorders. However, the effects of HPIV3 infection on nasal epithelial cells have not been well defined.

The aim of this study was to evaluate the effect of the HPIV3 infection on cultured human nasal epithelial cells (HNECS) and the release of interferon gamma and other cytokines.
\end{abstract}

Methods: RPMI 2650, a human nasal epithelial cell line was cultured into confluence and was infected with HPIV3 ( $\mathrm{MOI}$ of $0.1,0.01$ and 0.001). The protein release into supernatants and mRNA expression of selected cytokines were assessed 24, 48 and $72 \mathrm{~h}$ after infection. Cytokine concentrations in supernatants were measured by ELISA and expression of cytokine mRNA in RPMI 2650 cells confirmed by real time RT-PCR analysis.

Results: HNECs infection with HPIV3 did not induce cytotoxicity for at least 48 hours, but significantly increased IFN- $\gamma$ protein concentration in the cell supernatants at $24 \mathrm{~h}$ and $48 \mathrm{~h}$ post infection (by 387\% and $485 \%$ respectively as compared to mock infected cells). At $24 \mathrm{~h}$ a significant increase in expression of mRNA for IFNy was observed. RANTES protein concentration and mRNA expression were significantly increased at $72 \mathrm{~h}$ after infection (mean protein concentration: $3.5 \pm 1.4 \mathrm{pg} / \mathrm{mL}$ for $0.001 \mathrm{MOI}, 10.8 \pm 4.6 \mathrm{pg} / \mathrm{mL}$ for $0.01 \mathrm{MOl}$ and $61.5 \pm 18.4 \mathrm{pg} / \mathrm{mL}$ for 0.1 $\mathrm{MOI}$ as compared to $2.4 \pm 1.3 \mathrm{pg} / \mathrm{mL}$ for uninfected cells). No measurable concentrations of TNF-a, IL-10, TSLP, IL-8, GM-CSF or eotaxin, were detected in virus infected cells supernatants.

Conclusions: HPIV3 effectively infects upper airway epithelial cells and the infection is associated with induction of IFN- $\gamma$ and generation of RANTES.

Keywords: PIV3, Human parainfluenza virus 3, Nasal epithelium, IFN- $\gamma$, RANTES, RPMI cells

\section{Introduction}

Human parainfluenza viruses (HPIVs) which belong to the family Paramyxoviridae are enveloped, negative-strand RNA viruses and are common cause of acute airway respiratory illness in children and adults [1]. Out of four recognized serotypes PIV1 and PIV2 are leading causes of

\footnotetext{
* Correspondence: marek.kowalski@csk.umed.lodz.pl

'Department of Immunology, Rheumatology and Allergy, Chair of Clinical Immunology and Microbiology, Medical University of Lodz, Lodz, Poland ${ }^{4}$ Healthy Ageing Research Centre, Medical University of Lodz, Lodz, Poland Full list of author information is available at the end of the article
}

laryngotracheobronchitis in children, while PIV4 is a common respiratory pathogen similar to PIV3 in clinical presentation [2]. PIV3 is usually associated with bronchiolitis and pneumonia, and is among the most common cause of hospitalization in children [3-6]. In addition both in children and adults PIV3 infections have been implicated in exacerbation of bronchial asthma [7,8]. HPIV infection usually starts in the nose, and then spreads to the par nasal sinuses, Eustachian tubes, larynx, and eventually to the lower airways [9]. In upper airways of healthy adults the HPIV infection usually causes mild and transient 
symptoms (common cold) [3], but the role of HPIV in exacerbation of chronic upper airway diseases (rhino sinusitis) is largely unknown. In one study PIV3 was detected in HNECs from $88 \%$ of patients with post viral olfactory dysfunction as compared to $9 \%$ of control patients [10] suggesting potential involvement of PIV3 infection into the upper airway pathology.

Airway epithelium is the first line of defense during respiratory infection, and viral infection of lower airway epithelium with human respiratory viruses (rhinovirus, RSV or influenza) induce generation of a variety of cytokines, chemokines and interferons (including IFNs type I $(\alpha, \beta)$ or type III $(\lambda))$, which are involved in the host defense and development of the airway inflammation [11-14]. However, few published studies evaluated parainfluenza virus interaction with the airway epithelium and little is known about the upper airway epithelial response to HPIVs infection $[15,16]$.

Type I and type III, but not type II interferon (IFN- $\gamma$ ) are the predominant interferons induced by respiratory viruses in nasal epithelial cells [17]. IFN- $\gamma$ is a cytokine with direct antiviral activity, capable of promoting NK cells and virus specific-T cells cytotoxicity, thus is considered an important molecule involved in antiviral host defense. Acting via its receptor IFN- $\gamma$ activates hundreds of genes leading to pro-inflammatory effects by increasing antigen processing and presentation, and anti-inflammatory effects due to its apoptotic and anti-proliferative functions. IFN- $\gamma$ may interact with the airway epithelium triggering specific receptors, and leading to reduction in STAT6 phosphorylation [18]. In the mouse model of asthma IFN- $\gamma$ signaling through the airway epithelium inhibited mucus and chitinases production, and systemic eosinophilia independent of Th2 cell activation, suggesting its potential role in the modulation of asthmatic inflammation [19]. IFN- $\gamma$, has been considered to be mainly of lymphoid origin (produced mainly by $\mathrm{T}$ cells and natural killer cells) and relatively few studies investigated expression of IFN- $\gamma$ by the airway epithelial cells [20].

Having in mind, the lack of experimental data on the HPIV interaction with the upper airway epithelial cells, and the paucity of information on the immune responses of the airway epithelium to HPIV3 infection, we employed human upper epithelial cell line (RPMI 2650) culture model to study virus-induced production of IFN- $\gamma$ and pro-inflammatory cytokines.

\section{Materials and methods}

\section{Cell and viral culture}

Human nasal epithelial cells RPMI 2650 were obtained from the American Type Culture Collection (ATCC, Manassas, VA, USA). The cells were cultured in Eagle's Minimum Essential Medium with Earle's salt (Sigma, St. Louis, MO, USA), supplemented with $2 \mathrm{mM}$ L-glutamine
(Sigma), 10\% fetal bovine serum (FBS, Invitrogen, Life Technologies, CA, USA) and penicillin $100 \mathrm{U} / \mathrm{mL}$ (Sigma), streptomycin $100 \mu \mathrm{g} / \mathrm{mL}$ (Sigma), amphotericin B $2.5 \mu \mathrm{g} / \mathrm{mL}$ (Sigma) at $37^{\circ} \mathrm{C}$ with $5 \% \mathrm{CO}_{2}$ in humidified air. The culture medium was changed every 48 hours. The cells were seeded in $25 \mathrm{~cm}^{2}$ or $75 \mathrm{~cm}^{2}$ polystyrene cell-culture flasks (Becton Dickinson Ltd, Oxford, U.K) and were grown to 90\% confluence. When cells reached confluence they were trypsinized with $0.1 \%$ trypsin-EDTA solution (Sigma) and cells were transferred to 24-well culture plates (BD Ltd) for further experiments.

HPIV type 3 was obtained from the American Type Culture Collection (ATCC, Manassas, VA, USA) and propagated in monkey kidney-derived LLC-MK2 cells (ATCC, Manassas, VA, USA). Viral stocks were prepared by infecting monolayer cultures of LLC-MK2 cells until cytopathic effects (CPE) were fully developed. Viral supernatant fluid was collected by centrifugation at $3000 \mathrm{rpm}(960 \times g)$ in an Eppendorf 5810R centrifuge (Eppendorf, Hamburg, Germany) equipped with an A-4-62 rotor (Eppendorf) for $10 \mathrm{~min}$ to clear cellular debris and frozen in aliquots at $-80^{\circ} \mathrm{C}$. All infections were performed on LLC-MK2 cell monolayers in serum-free medium. Virus titers were determined based on the $50 \%$ tissue culture infective dose (TCID50) assay by infecting LLC-MK2 cells with serial 10 -fold dilutions of each virus stock. Infected cells were incubated at $37^{\circ} \mathrm{C}$ and CPE monitored on a daily basis. The TCID50 was calculated using the method of Reed and Muench. CPE was assessed by visual assessment and by assessment of the continuity of the monolayer after fixation in methanol (Sigma) and staining with $0.1 \%$ crystal violet (Sigma).

\section{Infection of cells with PIV3}

RPMI 2650 cells cultured into confluence were placed in medium without serum or additives and then infected with PIV3 at multiplicities of infection (MOI) ranging from 0.001 to 1 . After $1 \mathrm{~h}$ of incubation at room temperature, the inoculum was removed, and the cells were further cultured with MEM supplemented with $2 \%$ FCS. The cells or supernatants were harvested at relevant time point. The virus $\mathrm{CPE}$ and viability of infected cells were assessed 4,8 , 24, 48 and $72 \mathrm{~h}$ after infection.

\section{Viability assay}

Cell viability was assessed using the MTT assay. The RPMI 2650 cells were trypsinized, replated in 96-well plates and allowed to attach overnight. Fresh medium containing PIV3 was added to the cells. On specified time points, the culture media was removed, and MTT [thiazolyl blue tetrazolium bromide, 3-(4, 5-dimethylthiazol2-yl)-2, 5-diphenyltetrazolium bromide] (Sigma) was added to each well and the plates were incubated at $37^{\circ} \mathrm{C}$ for $3 \mathrm{~h}$. The reaction was stopped and after removing the medium, 
DMSO was added to solubilize the blue-colored tetrazolium. The absorbance at $570 \mathrm{~nm}$ was determined using an ELISA plate reader. Each assay point was performed in triplicate and the assays were performed on at least three separate occasions with similar results.

\section{Measurement of mediators}

TNF- $\alpha$, IL-10, TSLP, IL-8, RANTES, eotaxin, GM-CSF and IFN- $\gamma$ levels were measured in cell supernatants 24 , 48 and $72 \mathrm{~h}$ after infection with HPIV3 (MOI of 0.001, 0.01 and 0.1 ) by commercially available ELISA kits (R\&D Systems, Minneapolis, MN, USA) according to the manufacturer's specifications.

The sensitivity of the immunoassays was as follows: RANTES 3 pg/ml; IL-10 3.9 pg/mL, TSLP $9.87 \mathrm{pg} / \mathrm{mL}$, IL-8 1.5-7.5 pg/mL; eotaxin $5 \mathrm{pg} / \mathrm{mL}$; GM-CSF $3 \mathrm{pg} / \mathrm{mL}$, IFN- $\gamma 1.8 \mathrm{pg} / \mathrm{mL}$.

\section{Real time PCR}

Expression of cytokine mRNA in RPMI 2650 cells was evaluated after reverse transcription with real-time polymerase chain reactions. Total cellular RNA was extracted from epithelial cells using RNeasy mini kit (Qiagen, Limburg, Holand) and reverse transcription was performed with Omniscript RT kit (Qiagen). Real-time fluorescent detection PCR product analysis was performed by using iQ SYBR-Green Supermix (Bio-Rad, Hercules, CA, USA) according to instrument recommendations (StepOnePlus Real Time PCR System, Applied Biosystems, Carlsbad, California). PCR amplification of cDNA was performed in a reaction mixture containing $1 \mu \mathrm{L}$ cDNA, $1 \mu \mathrm{L}$ forward and $1 \mu \mathrm{L}$ reverse primers, $7 \mu \mathrm{L} \mathrm{H}_{2} \mathrm{O}$ and $10 \mu \mathrm{L}$ iQ SYBR GreenSupermix in a total volume of $20 \mu \mathrm{L}$. Reaction conditions were as follows: $95^{\circ} \mathrm{C}$ for $5 \mathrm{~min}$, followed by 35 cycles of $95^{\circ} \mathrm{C}$ for $30 \mathrm{sec}, 35$ cycles of different temperatures for $1 \mathrm{~min}$ and 35 cycles of $72^{\circ} \mathrm{C}$ for $1 \mathrm{~min}$. Annealing temperatures were as follows: $60^{\circ} \mathrm{C}$ for IFN- $\gamma$ and $61^{\circ} \mathrm{C}$ for RANTES. Relative quantification of different transcripts was determined with the $2^{-\Delta \Delta C T}$ method using $\beta$-actin as an endogenous control.

Primers specific for RANTES and IFN- $\gamma$ were purchased from Eurogentec (Eurogentec, Liege, Belgium). The sequences of the primers were as follows: RANTES: Forward 5'- CGC TGT CAT CCT CAT TGC TA -3', Reverse 5'-GAG CAC TTG CCA CTG GTG TA-3'; IFN- $\gamma$ : Forward 5'-ATA TTG CAG GCA GGA CAA CC-3', Reverse 5' -TCA TCC AAG TGA TGG CTG AA$3 ' ; \beta$-actin: Forward 5' - AGA AGG ATT CCT ATG TGG GCG-3', Reverse 5' - CAT GTC GTC CCA GTT GGT GAC-3'.

\section{Statistical data analysis}

Data are presented as means and standard errors of the means. Statistical analyses of the mediator concentrations were performed using Kruskal-Wallis ANOVA, followed by Wilcoxon matched-pairs signed-rank test. Alternatively, Mann-Whitney U test was performed. Subsequent post hoc analysis was conducted using the Bonferroniadjusted $\alpha$ method. All statistical analyses were performed using Statistica version 10 (StatSoft Inc.). Values of p lower than 0.05 were considered as statistically significant.

\section{Ethics statement}

The study was approved by ethics committee of the Medical University of Lodz (RNN/121/12/KE 19/06/2012).

\section{Results}

\section{HPIV3 cytotoxicity for RPMI 2650 cells}

To determine whether HPIV3 replication in RPMI 2650 cells had any cytotoxic or cytopathic effect, cell cultures were infected with the virus and observed using an inverted microscope for the development of cytopathic effect up to $96 \mathrm{~h}$ post inoculation (p.i.). Any cytopathic effect (rounding, bridging, cell lysis, and syncytium formation) was observed after $72 \mathrm{~h}$ and at the highest MOI of 1. (Figure 1) When monolayers were stained with crystal violet, no disruption of the cell layer could be observed before $72 \mathrm{~h}$. In order to assess the effect of virus infection on cells' viability, the culture media was removed at specified time points, and MTT was added to each well. At 24, 48 and $72 \mathrm{~h}$ there was no difference in cell viability between the infected (MOI of $0.0001,0.001$, 0.01 , and 0.1 ) and uninfected cells (Figure 2). Decreased cell viability occurred at $72 \mathrm{~h}$ after virus infection at 1 MOI and this effect was pronounced $96 \mathrm{~h}$ after infection. Based on these experiments optimal MOI and time points were chosen for further experiments.

\section{Cytokine release and expression in nasal epithelial cells in} response to HPIV3 infection

IFN- $\gamma$ protein was detected in non-infected cell supernatants at $24 \mathrm{~h}$ (mean concentration $3.2 \pm 1.2 \mathrm{pg} / \mathrm{mL}$ ), $48 \mathrm{~h}$ (mean $2.8 \pm 0.9 \mathrm{pg} / \mathrm{mL}$ ) and $72 \mathrm{~h}$ (mean $2.9 \pm 1.9 \mathrm{pg} / \mathrm{mL}$ ). PIV3 infection significantly increased in IFN- $\gamma$ protein level at 24 (by mean 387\%) and $48 \mathrm{~h}$ (by mean $485 \%$ ), post infection but the level significantly decreased at $72 \mathrm{~h}$. Figure 3A The increase in the IFN- $\gamma$ protein concentration at $24 \mathrm{~h}$ was significant for all three MOI as compared

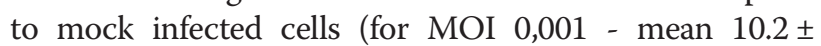
$3.1 \mathrm{pg} / \mathrm{mL}$, MOI $0,01-$ mean $12.4 \pm 2.9 \mathrm{pg} / \mathrm{mL}$ and MOI 0,1 - mean $14,8 \pm 2.3 \mathrm{pg} / \mathrm{mL}$ ) Figure 3B.

IFN- $\gamma$ mRNA expression increased significantly at $24 \mathrm{~h}$ by $174 \%$ over non-infected control and then decreased as compared to control by $28 \%$ and $66 \%$ at $48 \mathrm{~h}$ and $72 \mathrm{~h}$ after infection respectively. Figure $3 \mathrm{C}$.

Out of 7 cytokines measured in HNECs supernatants after HPIV3 infection only RANTES protein was detectable. No measurable concentrations of TNF- $\alpha$, IL-10, IL-8, 


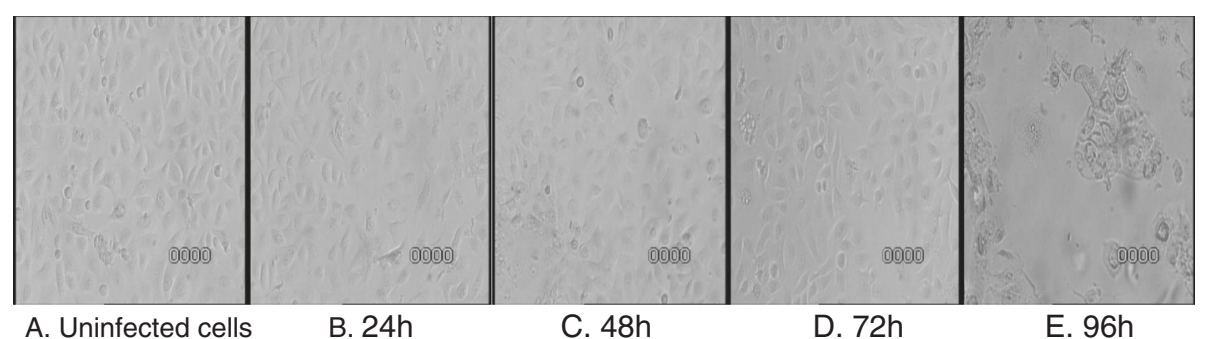

Figure 1 Confluent RPMI 2650 cells monolayers under the light microscope (100x). A. non-infected; B, C, D, E - infected with PIV3 at an $\mathrm{MOI}$ of 0.1 at different time-points.

exotaxin, GM-CSF and TSLP were detected in both uninfected and virus-infected cells supernatants.

RANTES protein was undetectable in supernatants collected at $24 \mathrm{~h}$, but was detected at $48 \mathrm{~h}$ in supernatants from uninfected and PIV3 infected cells (0.1MOI) (mean concentration $6.1 \pm 3.2 \mathrm{pg} / \mathrm{mL}$ and $7.5 \pm 2.1 \mathrm{pg} / \mathrm{mL}$ ) and significantly increased at $72 \mathrm{~h}$ p.i. (mean concentration $61.5 \pm 18.4 \mathrm{pg} / \mathrm{mL}$ as compared to $9.3 \pm 2.8 \mathrm{pg} / \mathrm{mL}$ in noninfected cells). Figure 4A The increase in RANTES protein release at $72 \mathrm{~h}$ was virus dose-dependent. Figure 4B. RANTES mRNA expression slightly increased already at $24 \mathrm{~h}$ (mean 15\% increase over non-infected control) and at $48 \mathrm{~h}$ (mean $51 \%$ increase), but was significantly augmented (mean 184\% increase) at $72 \mathrm{~h}$ Figure 4C.

\section{Discussion}

Our study demonstrated for the first time, that human airway epithelial cells may generate IFN- $\gamma$ in response to virus infection. Generation of IFN- $\gamma$ by epithelial cells tended to be virus dose-dependent and the maximal signal for IFN- $\gamma$ mRNA expression was observed already at $24 \mathrm{~h}$ after infection together with significant increase in IFN- $\gamma$ protein concentration in the cell supernatant. Interestingly, IFN- $\gamma$ protein concentration decreased to baseline level at $72 \mathrm{~h}$ post infection in parallel to decreased IFN- $\gamma$ mRNA expression. At $72 \mathrm{~h}$ post infection the cells maintained full viability and RANTES expression reached the highest value, indicating that the IFN- $\gamma$ generation was a truly transient phenomenon. Our observations contrast with previous study that failed to detect IFN- $\gamma$ mRNA expression or IFN- $\gamma$ protein secretion in primary human airway epithelial cells in response to rhinovirus (RV16) infection [14]. However, IFN- $\gamma$ was shown to be expressed in the alveolar cell line A549 after bacterial infections: IFN $-\gamma$ mRNA expression was detected in cells infected with Mycoplasma pneumoniae and Chlamydia pneumoniae [21,22] and release of high concentrations of IFN- $\gamma$ was shown in A549 cells infected with Mycobacterium tuberculosis [20]. These observations suggest, that IFN- $\gamma$ generation by airway epithelial cells may depend on the infecting pathogen and/or on the epithelial cell line tested. In an ex vivo study, IFN- $\gamma$ expression in PBMC of infants varied significantly depending on the nature of the viral pathogen (parainfluenza, rhinovirus, adenovirus or RSV) and severity of clinical illness [23]. Differential capacity of respiratory viruses to generate IFN- $\gamma$ response in the airway epithelial cell may be important to determine their ability to promote Th1 immune response, which especially in infants may have consequences for development of allergic sensitization and asthma later in life. While these observations require to be confirmed in the

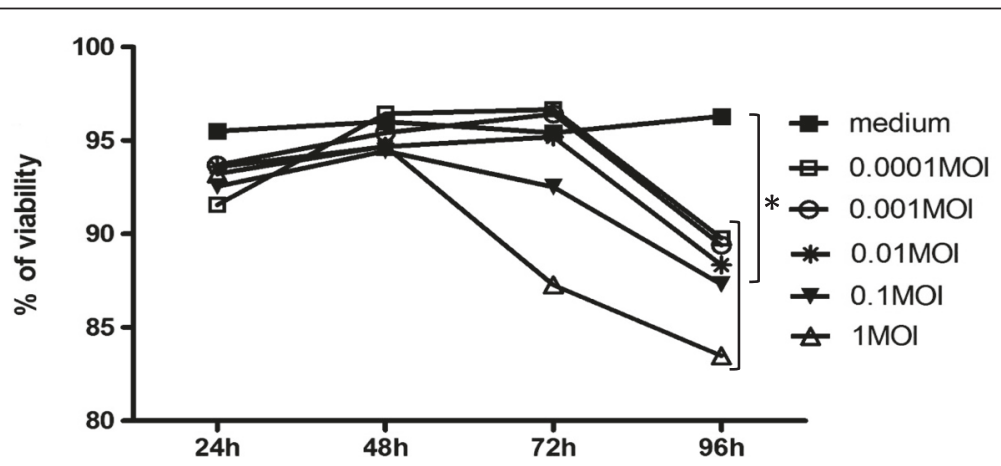

Figure 2 Cell viability changes of PIV3-infected RPMI 2650 cells. Cells were seeded into 24-well culture plates and infected with PIV3 at different MOI for indicated hours. Cell viability was detected by MTT assay. $(n=10)$. 


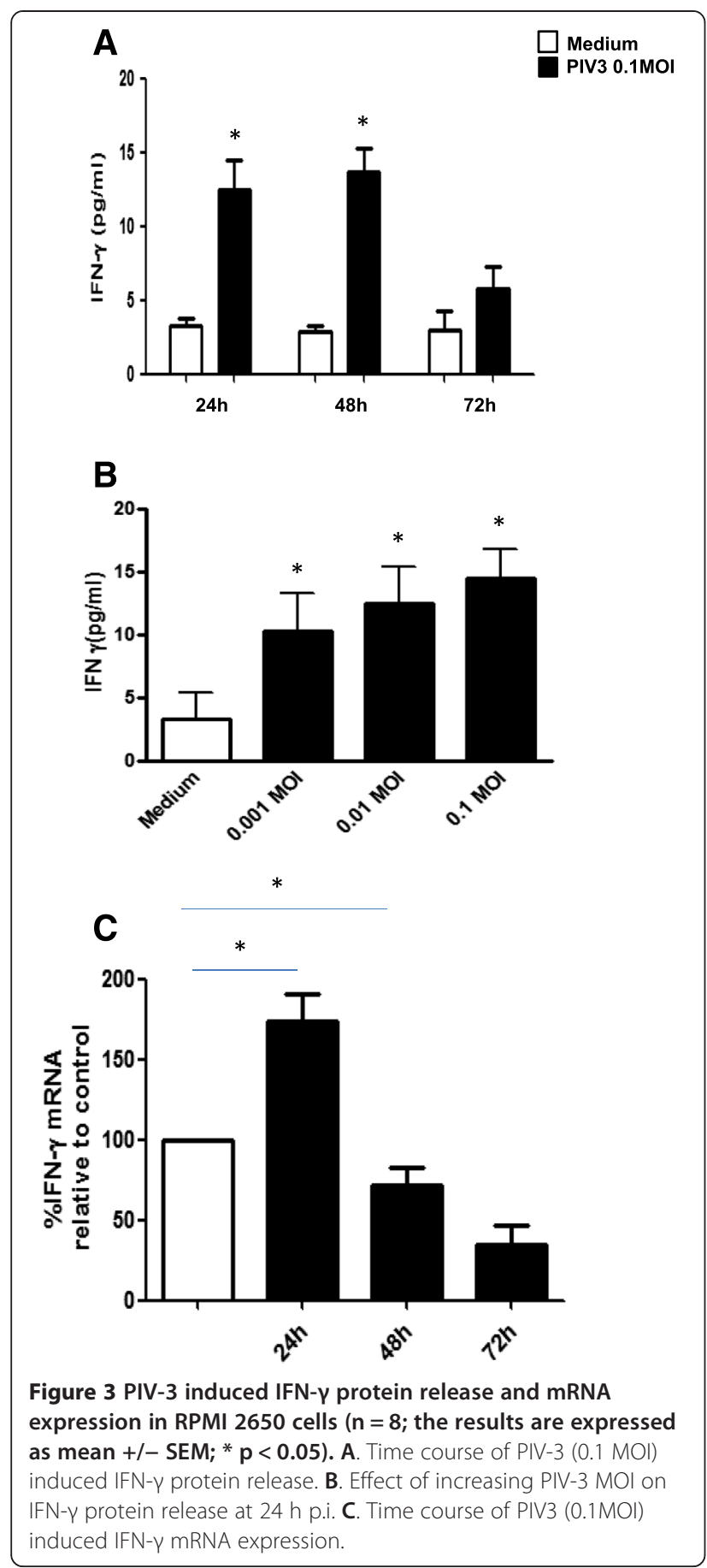

primary airway epithelial cells, they may have potential implications for our understanding of the pathophysiology of PIV-3 induced respiratory infection. IFN- $\gamma$ induces genes promoting antiviral mechanisms, which include leukocyte recruitment, antigen processing and presentation, cell proliferation and apoptosis, leading to limitation of the viral infection and its consequences [24]. IFN- $\gamma$ actions through the airway epithelium has been shown to inhibit eosinophil generation in the bone

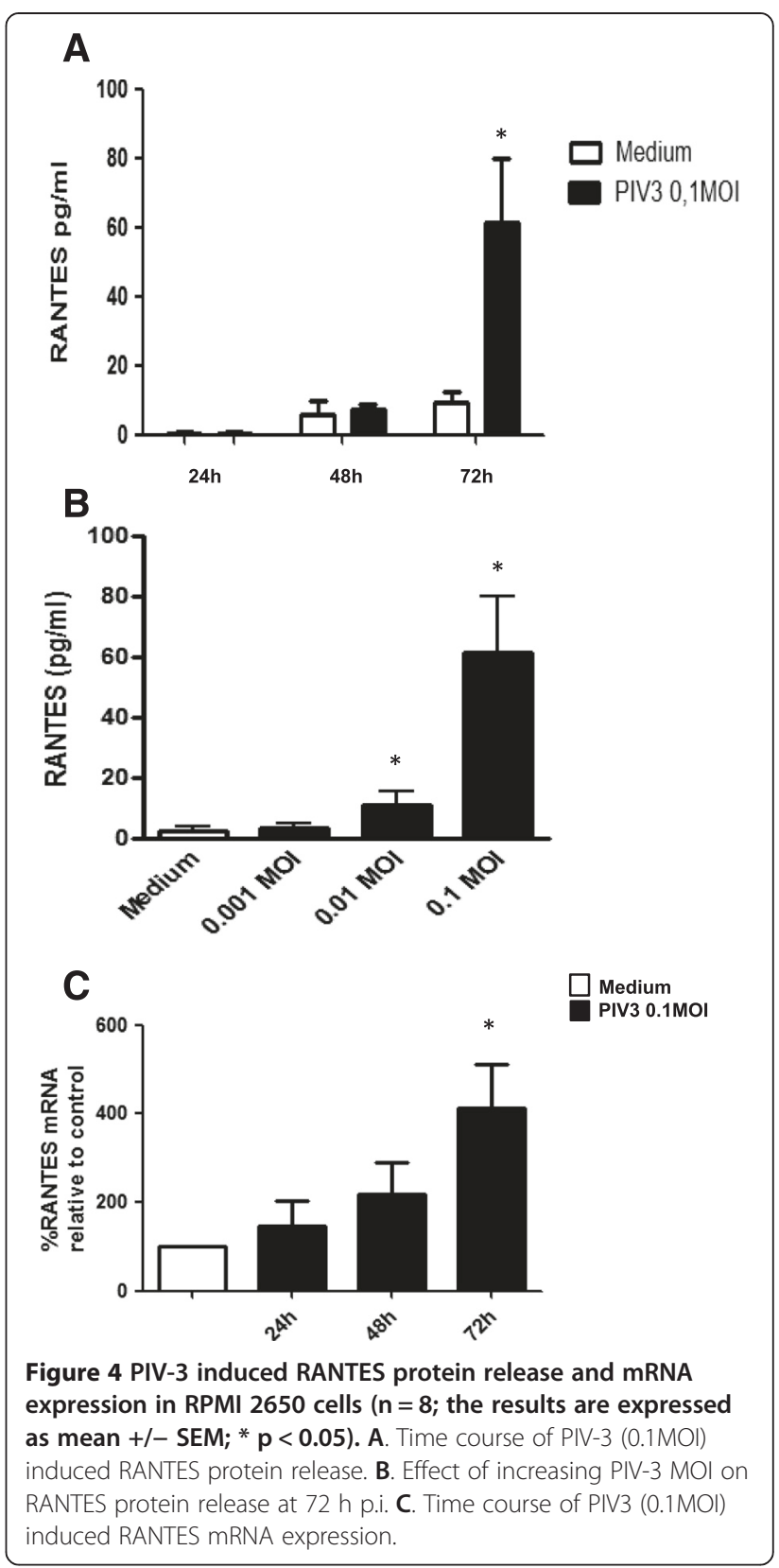

marrow, limiting airway obstruction and inflammation in the animal model of asthma [19]. Thus, induced by virus generation of IFN- $\gamma$ in epithelial cells must be considered as a component of natural host defense counteracting induction of pro inflammatory mediators and leading to limitation of the tissue destruction. IFN- $\gamma$ may act in concert with type I (IFN- $\alpha$, IFN- $\beta$ ) and type III (IFN- $\lambda$ ) interferons, which are generated in response to viral infections in upper and lower airway epithelial cells and may limit virus-induced injury $[17,25]$.

On the other hand it has been documented, that local production of IFN- $\gamma$ as well as other proinflammatory cytokines (CCL3, CCL 11) in the lungs of mice infected 
with murine parainfluenza (Sendai Virus) correlated with severity of the lung disease [26]. In cotton rat model of Human Parainfluenza 3 laryngotracheitis IFN- $\gamma$ mRNA expression in laryngeal tissues was increased by infection and corticosteroid treatment, which reduced the extent of lesions, led to a measurable reduction of IFN $\gamma$ expression [27]. Accordingly in children with croup parenteral dexamethasone or inhaled budesonide are used in the early treatment of the diseases, and effectiveness of GCS has been associated with decreased IFN- $\gamma$ mRNA expression [28]. Thus, further studies with specific inhibitors of IFN- $\gamma$ have to be carried out to elucidate if virus induced IFN- $\gamma$ generation by epithelial cells has pro or anti-inflammatory function.

HPIV3 has been shown to exacerbate preexisting asthma presumably by setting off the inflammatory cascade with generation of other than IFN- $\gamma$ mediators and cytokines $[7,8,29]$. In human upper airway epithelial cell line infected with HPIV3 out of 7 cytokines measured only RANTES could be detected in the supernatants. A significant increase in RANTES protein was observed at $72 \mathrm{~h}$, when IFN- $\gamma$ concentration was already decreased. The induction of high RANTES levels in PIV3 infected of upper airway epithelial cells is consistent with other studies on bronchial epithelial cell monolayers infected with HPIVs and other viruses from Paramyxoviridae family [15,30,31]. In human ciliated airway epithelium infected with PIV3 RANTES concentrations increased gradually from day 2 through day 5 post infection [15]. Increased RANTES secretion was also found after RSV infection in bronchial epithelial cells $[30,31]$ and elevated RANTES levels were reported in nasopharyngeal secretions from RSV-positive children [32]. Local production of chemokines has been also observed in children with PIV-positive airway respiratory infections: PIV-infected patients had higher nasal wash concentrations of chemokines such as RANTES/CCL5, IL-8/CXCL8, MIP$1 \alpha / C C L 3$, MIP-1 $\beta /$ CCL4, CXCL9 and CXCL10 as compared to uninfected control patients [33]. Production of pro-inflammatory chemokines by HPIV3 infected airway epithelial cells may contribute to development of respiratory symptoms in infected healthy individuals, but may also contribute to the exaggerated host inflammatory response associated with virus - induced exacerbations of chronic inflammatory airways diseases .

Although we were not able to detect any measurable concentrations of TNF- $\alpha$, IL-10, IL- 8 , exotaxin, GM-CSF and TSLP in either uninfected and virus-infected cells supernatants our data cannot be directly referred to in vivo studies. For example, the release of cytokines and chemokines from airway epithelial cells is strongly affected by the presence of $\mathrm{T}$ lymphocytes, which may be responsible for less cytokine generation in isolated cell line model [34]. Furthermore, cytokine production in response to virus infection is both virus and cell type specific and even the same virus may evoke various cytokine response in upper and upper and lower primary human epithelial cells [35]. Thus, is also possible that the lack of production of some proinflammatory cytokines in our model results either from not sufficient activation of cells by PIV3 or reflect specific type o response to HPIV3 virus in RPMI cell line.

RPMI 2650 cell line used in this study have been shown to closely resemble normal human upper airway epithelium with respect to its karyotype, cytokeratin expression and the presence of mucoid material on the cell surface, and were previously used to study interactions of the airway epithelium with cytokines and allergens [36-38]. This is the first study documenting in vitro infection of human nasal epithelial cells (RPMI 2650 line) with HPIV3, and its association with the release of cytokines; in all previous studies only HPIV infections of lower airway epithelium have been examined $[15,16,39]$. In our model HNECs infected with HPIV3 did not show apparent cytopathology for up to $92 \mathrm{~h}$ after infection, and cells viability was not changed up to $48 \mathrm{~h}$, and at $72 \mathrm{~h}$ only with the highest virus titres was significantly decreased. These results are consistent with observations of Zhang et al $[39,40]$. who during the lower airway epithelial cells culture, grown at an air-liquid interface, observed little PIV3 virus cytotoxicity.

In conclusion we have demonstrated that HPIV3 effectively infects upper airway epithelial cells and the infection is associated with induction of interferon gamma. Further investigations involving primary human cells and IFN- $\gamma$ inhibitors may allow for understanding the role of the epithelium derived IFN- $\gamma$ in the pathophysiology of HPIV3 induced and/or exacerbated respiratory disorders.

\section{Abbreviations}

HPIVs: Human parainfluenza viruses; PIV3: Parainfluenza virus type 3; HPIV3: Human parainfluenza virus type 3; RSV: Respiratory syncytial virus; HNECS: Human nasal epithelial cells.

\section{Competing interests}

The authors declare that they have no competing interests.

\section{Authors' contributions}

ALP designed, performed and analyzed all the experiments and prepared the manuscript. EP, ZL assisted in data analysis and preparation of the manuscript. MB, MJ, SM, performed experiments. MK performed experiments and assisted in data analysis. MLK designed experiments, supervised all aspects of the project and prepared the manuscript. All authors read and approved the final manuscript

\section{Acknowledgments}

The study was supported by the Maestro Grant from the National Research Center (Grant Nr UMO-2011/02/A/NZ5/00341). The authors have been partially supported by The Healthy Aging Research Center project (REGPOT-2012-2013-1, 7FP).

\section{Author details}

'Department of Immunology, Rheumatology and Allergy, Chair of Clinical Immunology and Microbiology, Medical University of Lodz, Lodz, Poland. ${ }^{2}$ Department of Microbiology, Immunology and Laboratory Medicine, Chair of Clinical Immunology and Microbiology, Medical University of Lodz, Lodz, 
Poland. ${ }^{3}$ Laboratory of Molecular Virology and Biological Chemistry, Institute of Medical Biology, Polish Academy of Sciences, Lodz, Poland. ${ }^{4}$ Healthy Ageing Research Centre, Medical University of Lodz, Lodz, Poland.

\section{Received: 17 July 2014 Accepted: 20 January 2015} Published online: 21 February 2015

\section{References}

1. Hall CB. Respiratory syncytial virus and parainfluenza virus. N Engl J Med. 2001;344:1917-28.

2. Frost HM, Robinson CC, Dominguez SR. Epidemiology and clinical presentation of parainfluenza type 4 in children: a 3-year comparative study to parainfluenza types 1-3. J Infect Dis. 2014;209:695-702

3. Liu WK, Liu Q, Chen DH, Liang HX, Chen XK, Huang WB, et al. Epidemiology and clinical presentation of the four human parainfluenza virus types. BMC Infect Dis. 2013;13:28

4. Henrickson KJ. Parainfluenza viruses. Clin Microbiol Rev. 2003;16:242-64.

5. Laurichesse H, Dedman D, Watson JM, Zambon MC. Epidemiological features of parainfluenza virus infections: laboratory surveillance in England and Wales, 1975-1997. Eur J Epidemiol. 1999:15:475-84.

6. Mizuta K, Saitoh M, Kobayashi M, Tsukagoshi H, Aoki Y, Ikeda T, et al. Detailed genetic analysis of hemagglutinin-neuraminidase glycoprotein gene in human parainfluenza virus type 1 isolates from patients with acute respiratory infection between 2002 and 2009 in Yamagata prefecture. Japan Virol J. 2011:8:533.

7. Azevedo AM, Durigon EL, Okasima V, Queiroz DA, de Moraes-Vasconcelos D, Duarte AJ, et al. Detection of influenza, parainfluenza, adenovirus and respiratory syncytial virus during asthma attacks in children older than 2 years old. Allergol Immunopathol (Madr). 2003;31:311-7.

8. Matsuse $H$, Kondo $Y$, Saeki S, Nakata H, Fukushima C, Mizuta $Y$, et al. Naturally occurring parainfluenza virus 3 infection in adults induces mild exacerbation of asthma associated with increased sputum concentrations of cysteinyl leukotrienes. Int Arch Allergy Immunol. 2005;138:267-72.

9. Schomacker H, Schaap-Nutt A, Collins PL, Schmidt AC. Pathogenesis of acute respiratory illness caused by human parainfluenza viruses. Curr Opin Virol. 2012;2:294-9.

10. Wang JH, Kwon $\mathrm{HJ}$, Jang $\mathrm{YJ}$. Detection of parainfluenza virus 3 in turbinate epithelial cells of postviral olfactory dysfunction patients. Laryngoscope. 2007:117:1445-9.

11. Message SD, Johnston SL. Host defense function of the airway epithelium in health and disease: clinical background. J Leukoc Biol. 2004;75:5-17.

12. Schroth MK, Grimm E, Frindt P, Galagan DM, Konno SI, Love R, et al. Rhinovirus replication causes RANTES production in primary bronchial epithelial cells. Am J Respir Cell Mol Biol. 1999;20:1220-8.

13. Terajima M, Yamaya M, Sekizawa K, Okinaga S, Suzuki T, Yamada N, et al. Rhinovirus infection of primary cultures of human tracheal epithelium: role of ICAM-1 and IL-1beta. Am J Physiol. 1997;273:L749-59.

14. Chen Y, Hamati E, Lee PK, Lee WM, Wachi S, Schnurr D, et al. Rhinovirus induces airway epithelial gene expression through double-stranded RNA and IFN-dependent pathways. Am J Respir Cell Mol Biol. 2006;34:192-203.

15. Schaap-Nutt A, Liesman R, Bartlett EJ, Scull MA, Collins PL, Pickles RJ, et al. Human parainfluenza virus serotypes differ in their kinetics of replication and cytokine secretion in human tracheobronchial airway epithelium. Virology. 2012;433:320-8

16. Bartlett EJ, Hennessey M, Skiadopoulos MH, Schmidt AC, Collins PL, Murphy $B R$, et al. Role of interferon in the replication of human parainfluenza virus type 1 wild type and mutant viruses in human ciliated airway epithelium. J Virol. 2008:82:8059-70.

17. Okabayashi T, Kojima T, Masaki T, Yokota S, Imaizumi T, Tsutsumi H, et al. Type-III interferon, not type-I, is the predominant interferon induced by respiratory viruses in nasal epithelial cells. Virus Res. 2011;160:360-6.

18. Moynihan BJ, Tolloczko B, El Bassam S, Ferraro P, Michoud MC, Martin JG, et al. IFN-gamma, IL-4 and IL-13 modulate responsiveness of human airway smooth muscle cells to IL-13. Respir Res. 2008;9:84.

19. Mitchell C, Provost K, Niu N, Homer R, Cohn L. IFN-gamma acts on the airway epithelium to inhibit local and systemic pathology in allergic airway disease. J Immunol. 2011;187:3815-20.

20. Sharma M, Sharma S, Roy S, Varma S, Bose M. Pulmonary epithelial cells are a source of interferon-gamma in response to Mycobacterium tuberculosis infection. Immunol Cell Biol. 2007:85:229-37.
21. Yang J, Hooper WC, Phillips DJ, Talkington DF. Regulation of proinflammatory cytokines in human lung epithelial cells infected with Mycoplasma pneumoniae. Infect Immun. 2002;70:3649-55.

22. Yang J, Hooper WC, Phillips DJ, Tondella ML, Talkington DF. Induction of proinflammatory cytokines in human lung epithelial cells during Chlamydia pneumoniae infection. Infect Immun. 2003;71:614-20.

23. Aberle JH, Aberle SW, Rebhandl W, Pracher E, Kundi M, Popow-Kraupp T. Decreased interferon-gamma response in respiratory syncytial virus compared to other respiratory viral infections in infants. Clin Exp Immunol. 2004;137:146-50.

24. Schroder K, Hertzog PJ, Ravasi T, Hume DA. Interferon-gamma: an overview of signals, mechanisms and functions. J Leukoc Biol. 2004;75:163-89.

25. Khaitov MR, Laza-Stanca V, Edwards MR, Walton RP, Rohde G, Contoli M, et al. Respiratory virus induction of alpha-, beta- and lambda-interferons in bronchial epithelial cells and peripheral blood mononuclear cells. Allergy. 2009;64:375-86.

26. Suryadevara M, Bonville CA, Rosenberg HF, Domachowske JB. Local production of CCL3, CCL11, and IFN-gamma correlates with disease severity in murine parainfluenza virus infection. Virol J. 2013;10:357.

27. Ottolini MG, Porter DD, Blanco JC, Prince GA. A cotton rat model of human parainfluenza 3 laryngotracheitis: virus growth, pathology, and therapy. J Infect Dis. 2002:186:1713-7.

28. Hu X, Li WP, Meng C, Ivashkiv LB. Inhibition of IFN-gamma signaling by glucocorticoids. J Immunol. 2003;170:4833-9.

29. Takeyama A, Hashimoto K, Sato M, Sato T, Tomita Y, Maeda R, et al. Clinical and epidemiologic factors related to subsequent wheezing after virus-induced lower respiratory tract infections in hospitalized pediatric patients younger than 3 years. Eur J Pediatr. 2014;173:959-66.

30. Yoon JS, Kim HH, Lee Y, Lee JS. Cytokine induction by respiratory syncytial virus and adenovirus in bronchial epithelial cells. Pediatr Pulmonol. 2007:42:277-82.

31. Villenave R, O'Donoghue D, Thavagnanam S, Touzelet O, Skibinski G, Heaney LG, et al. Differential cytopathogenesis of respiratory syncytial virus prototypic and clinical isolates in primary pediatric bronchial epithelial cells. Virol J. 2011:8:43.

32. Murai H, Terada A, Mizuno M, Asai M, Hirabayashi Y, Shimizu S, et al. IL-10 and RANTES are elevated in nasopharyngeal secretions of children with respiratory syncytial virus infection. Allergol Int. 2007:56:157-63.

33. El Feghaly RE, McGann L, Bonville CA, Branigan PJ, Suryadevera M, Rosenberg HF, et al. Local production of inflammatory mediators during childhood parainfluenza virus infection. Pediatr Infect Dis J. 2010;29:e26-31.

34. Jornot L, Cordey S, Caruso A, Gerber C, Vukicevic M, Tapparel C, et al. T lymphocytes promote the antiviral and inflammatory responses of airway epithelial cells. PLoS One. 2011;6:e26293.

35. Lopez-Souza N, Favoreto S, Wong H, Ward T, Yagi S, Schnurr D, et al. In vitro susceptibility to rhinovirus infection is greater for bronchial than for nasal airway epithelial cells in human subjects. J Allergy Clin Immunol. 2009:123:1384-90. e1382

36. Pace E, Scafidi V, Di Bona D, Siena L, Chiappara G, Ferraro M, et al. Increased expression of IL-19 in the epithelium of patients with chronic rhinosinusitis and nasal polyps. Allergy. 2012;67:878-86.

37. Reichl S, Becker K. Cultivation of RPMI 2650 cells as an in-vitro model for human transmucosal nasal drug absorption studies: optimization of selected culture conditions. J Pharm Pharmacol. 2012;64:1621-30.

38. Salib RJ, Lau LC, Howarth PH. The novel use of the human nasal epithelial cell line RPMI 2650 as an in vitro model to study the influence of allergens and cytokines on transforming growth factor-beta gene expression and protein release. Clin Exp Allergy. 2005;35:811-9.

39. Zhang L, Bukreyev A, Thompson Cl, Watson B, Peeples ME, Collins PL, et al. Infection of ciliated cells by human parainfluenza virus type 3 in an in vitro model of human airway epithelium. J Virol. 2005;79:1113-24.

40. Zhang L, Collins PL, Lamb RA, Pickles RJ. Comparison of differing cytopathic effects in human airway epithelium of parainfluenza virus 5 (W3A), parainfluenza virus type 3 , and respiratory syncytial virus. Virology. 2011;421:67-77. 